\title{
Research on the Cross-border E-commerce Business Model of China's Export Enterprises
}

\author{
Dingjie $\mathrm{Xu}$ \\ Financial and Management Department \\ Chongqing College of Electronic Engineering \\ Chongqing, China
}

\begin{abstract}
In recent years, in the context of the obvious slowdown of global economic, cross-border e-commerce, as a new model of international trade, has bucked the trend and achieved rapid growth in performance and market size continuously. The rise of cross-border e-commerce business brings new opportunities for small and medium-sized export enterprises, so how to realize the layout and development of China's manufacturing industry from local to a global scale through cross-border e-commerce is crucial. This paper analyzes the problems existing in the current business model of China's export enterprises and gives countermeasures and suggestions respectively.
\end{abstract}

Keywords-export enterprise; cross-border e-commerce; countermeasures

\section{INTRODUCTION}

Since the cross-border e-commerce business model is involving customers, cross-border e-commerce platform, supply chain service and other contents, the problems in the business model are relatively diverse. This paper analyzes from four aspects: business foundation, operation mode, and business channel and business mechanism.

\section{PROBLEMS ANALYSIS IN CROSS-BORDER E- COMMERCE BUSINESS MODEL}

\section{A. Business Basis}

Brand is the value embodiment of products, is one of the important intangible assets of enterprises. On the subjective side, European countries and the United States usually attach great importance to enterprises or product brands, while many Chinese enterprises have relatively poor brand building awareness and do not realize the important role of brands in the development of enterprises. Objectively, export enterprises are under great pressure to survive with limited resources. Brand building takes a long time, which requires long-term investment from enterprises. It is very unlikely to gain profits through brand in a short time. Brand building has a high degree of specialization and needs to be familiar with all aspects of brand building design and be able to carry it out for a long time. Therefore, it is difficult for many enterprises to start brand building.

Brand awareness building is poor. Chinese companies usually give the impression that their products are cheap.
Cheap can help enterprises quickly open the international market to some extent, but in the long run, this old model of cheap and fast market occupation is not conducive to the long-term development of enterprises in overseas markets. As an important part of the transition from productionoriented enterprises to cross-border e-commerce enterprises, some enterprises gradually realize that in order to become bigger and stronger, they must establish brands. However, since brand building is a long and laborious work, many enterprises will naturally continue to attract enterprises and individual users quickly through the feature of low price when trying to enter the cross-border e-commerce market Subjectively, these enterprises ignore the special value of brand as an intangible asset.

Brand building business level is low. Export enterprises do not understand the content of brand building, mainly because the content of brand building is complex. Brand planning and Omni media promotion are only part of brand building, which has certain requirements on enterprise strategy, market channels and even the ability of brand building team. Enterprises are limited by their scale and profitability, and most of their income and energy are spent on the reconstruction and construction of enterprises, while the long-term construction and planning of enterprise brands are often neglected. Faced with the huge and unfamiliar overseas market, it is more difficult to build enterprise brand in the overseas market. When faced with sorting out enterprise brand in overseas market, export enterprises often have no way to start. Therefore, brand building has also become one of the weaknesses of export enterprises in overseas expansion.

\section{B. Mode of Operation}

It is difficult to grasp the proportion of traditional trade and cross-border e-commerce resources. In view of common problems such as insufficient exploitation of emerging markets and insufficient improvement of supporting services in the overseas expansion of Chinese cross-border ecommerce enterprises, the share of cross-border e-commerce exports in the total export business still has some room for improvement. Traditional trade is different from cross-border e-commerce in terms of business model. Traditional trade is usually relatively stable in terms of transaction volume, but cross-border e-commerce has a rapid growth rate and strong accumulation effect. In terms of overseas channel 
construction, they have totally different ideas. One focuses on offline promotion, while cross-border e-commerce companies prefer Internet promotion. Enterprises need to choose and balance how to coordinate and allocate resources in two businesses or even teams.

\section{Business Channels}

Poor supply chain needs integration ability. The overall scale of export enterprises is limited, which facilitates internal communication and coordination among enterprises, but there are also shortages of department personnel, personnel capacity, department setting and other entity departments. For the self-operation mode of export, it involves the integration and coordination of information flow, product flow and capital flow of enterprises, the comprehensive service before, during and after sales, and the coordination among enterprises of customers, suppliers and partners. All this poses a test for exporters. Faced with important departments and institutions in market activities such as customs, finance and logistics, enterprises usually have a low right to speak. In the process of resource integration, enterprises have a small range of options, relatively high costs and poor ability to integrate the whole supply chain.

\section{Business Mechanism}

First, internal and external policies and other information are inadequate. Cross-border e-commerce market is in the stage of development and cultivation. There are no mature rules and management methods for reference, and there are a lot of problems and uncertainties. Solving these problems involves customs, inspection and quarantine, state tax, foreign exchange administration and other government functional departments. Second, the overseas buyer is not familiar with the situation. At present, the development of cross-border e-commerce service industry is relatively lagging, and a complete supporting system has not yet been formed. Information asymmetry is still one of the main problems encountered by export enterprises in the process of developing cross-border e-commerce business. From the research of the complete industrial chain of cross-border ecommerce, most of the buyers and sellers are in different countries and regions, and they have some similarities in language and culture, which makes it difficult to communicate, especially in the case of export enterprises and the shortage of foreign language talents. At the same time, because of the background on both the buyer and the seller are not familiar with, cause at the time of purchase, the two sides are difficult to establish a mutual trust relationship, which puts forward higher requirements on cross-border electric business platform, export enterprise and how to use the platform service function, improve their credibility, promote enterprise cross-border trade transactions, become one of the bottlenecks of cross-border e-business enterprise development.

\section{COUNTERMEASURES AND SUGGESTIONS FOR OPTIMIZING CROSS-BORDER E-COMMERCE BUSINESS MODEL}

As a new mode of export, cross-border e-commerce business is changing rapidly from products to consumers, from consumers to cooperation mode, from cooperation mode to market competition. For internal development, enterprises need to combine their own advantages and characteristics, formulate short-term, medium-term and longterm development strategies and plans that are in line with their development stage, specific needs and goals, and select suitable cross-border e-commerce platforms based on their own plans, while paying attention to personnel training. The external development of enterprises needs to keep pace with The Times. In combination with national cross-border ecommerce policies and relevant laws and regulations, enterprises should follow the development planning steps of the government, enhance enterprise flexibility to meet market changes to some extent, seek improvement in stability.

\section{A. Stabilizing Business Foundation}

1) Brand position: Brand strategic planning is the basis and the guiding ideology of brand construction implementation. The important point of brand strategy is brand positioning, brand positioning to do the following content: consumer positioning, brand image positioning, product base positioning, price positioning, etc.

2) Creating a corporate brand: At present, there are many professional overseas trademark agencies at home and abroad, some cross-border e-commerce comprehensive service platforms and some trading platforms such as Ali Express, all of which can provide overseas trademark and enterprise registration services for China's export crossborder e-commerce enterprises. In terms of the basic elements of brand, enterprises should work from the aspects of brand name, brand design, brand core value and brand communication. The core of the dispute between JDB and Wang laoji is the competition of basic elements of the brand, with name, product packaging (brand design) as the focus and the carrier of brand value. Brand design and core values are closely related, and core values guide the design direction. When cross-border e-commerce enterprises carry out brand design, they are like physical enterprises, whose brand design affects their office environment, store image and product packaging. In addition, brand design of crossborder e-commerce enterprises affects the design of online stores and product display pages.

\section{B. Strengthening Business Channels}

It is necessary to optimize supply chain management. The reasonable optimization of supply chain can help enterprises to realize the channel sales, distribution and aftersales of products with the most economic and effective mean, and improve the user experience. The organic cooperation with the supply chain industry service enterprises, based on mutual trust, should protect the interests of both parties 
through the contract and make a good plan for the coordination mechanism of both parties. In terms of information service, facing various information services, enterprises should do a good job in the demand and planning of information release. Begin with the release of information; enterprises should grasp the content, fund control of information release in various channels. Product pricing, basic price is cost pricing, the enterprise in addition to consider the production cost. Logistics cost, foreign online publicity costs, foreign tax cost is included in the products within the scope of basic price considerations, through comprehensive accounting calculating the basis of product prices. In terms of channel price, it is necessary to combine overseas warehouse and B2B channel operators to make tiered pricing and control channel price based on reserving enough profit space for channel operators. In terms of retail price, it is the direct transaction price of foreign buyers. When specifying the price, it should also consider the domestic and foreign competitive price and the logistics price of foreign port to door.

\section{Exploring Business Mechanisms}

It is important to elect the right Cross-border Ecommerce Platform. Cross-border e-commerce platform features and modes are diverse, and enterprises need to first specify their own development strategies. After the development strategy is clear, according to different characteristics, select suitable business model, and target market and cross-border e-commerce platform matching the model. In terms of specific platform selection, it is recommended to choose large, comprehensive and worldrenowned e-commerce platforms with relatively complete services and strong comprehensive capacity, which cover most of the developed regions in the world. Choose the right market channel. In the overseas promotion process, crossborder e-commerce enterprises should pay special attention to the marketing channels of Internet channels, except Google search engine (bidding ranking), community marketing (Facebook, Twitter, space, etc.), BBS marketing, etc. Based on brand building, enterprises should pay attention to the design of marketing channels and supporting content. The passage for international, for example, is through the channel such as Facebook, Twitter, release relevant marketing soft wen, even the B2B marketing enterprise, individual buyers and corporate buyers staff are Facebook, Twitter, users of the APP, such as community social spread more easily accepted by the buyer, within the group were also more likely to establish the initial trust relationship.

\section{CONCLUSION}

To sum up, the development of the enterprise in crossborder electricity business made good under the tide of development, still need to continuously explore its own business model. China's export enterprises should be consider their own business situation, from stable business base, optimizing operating mode, strengthening business channel, doing a good job of cross-border business development and operation of electricity. At the same time, it should constantly adjust, explore the business mechanism suitable for the enterprise's own characteristics, and optimize the organizational structure, in order to seek the long-term development of the enterprise.

\section{REFERENCES}

[1] Liu Hongduo, Cai Xiao-shan. Study on Bilateral Trade Costs between China and Countries along the "One Belt And One Road" [J]. Economist, 2016(7): 92-100.

[2] Li Xudong. Comprehensive Service System of Cross-Border ECommerce Logistics Enterprises and its Empirical Research [J]. China circulation economy, 2015(11): 49-57.

[3] Zheng Hongming. Analysis of the Impact of Cross-Border E Commerce on China's Import and Export Trade from the Perspective of Industrial Chain [J]. Price monthly, 2016(5): 45-49.

[4] Shang Jing. Analysis of B2C Export Business of Small and MediumSized Foreign Trade Enterprises in Developing Cross-Border Trade [J]. Enterprise economics, 2015(5): 75-78.

[5] Liao Rundong. Difficulties and Countermeasures of Cross-Border ECommerce Retail Export of Small and Medium-sized Foreign Trade Enterprises [J]. Enterprise economy, 2017(11): 62-67. 